\title{
KONFIGURASI SISTEM KEAMANAN JARINGAN
}

\author{
Alcianno G. Gani
}

localghost2000@gmail.com

\begin{abstract}
Along with the development of technology in the world of computing, human needs are also increasingly complex in its use for the development of these technologies. This is something that is only natural and supports each other between both technology and human needs. Technology will continue to be created from time to time, from the simple to the very sophisticated technology. With technology, it is expected that all human activities can be solved more easily, quickly and accurately. One of them is the existence of a network system. Through the network there are many conveniences that can be felt including sharing hardware, sharing software, facilitating communication between network users and sharing data and information more easily. Long distances are no longer a barrier to being able to get data and information quickly and safely. In network systems also need to be considered the security problem in order to avoid things that are not desirable, such as being attacked by a virus or reading data by unwanted parties.

Keywords: Network, Security, Network Security, Network Security Configuration
\end{abstract}

\section{Pendahuluan}

Salah satu kemajuan perkomputeran yang bisa kita lihat dan nikmati pada masa sekarang ini adalah adanya sistem jaringan. Melalui sistem jaringan, komputer yang semula hanya bekerja sendiri (stand alone) sekarang telah dapat berkomunikasi dalam berbagi informasi atau sharing tanpa mengharuskan manusianya mendatangi secara fisik pada komputer yang memiliki informasi yang diinginkannya. Manfaatnya tentu sangat jelas, bahwa hal ini akan menghemat waktu dan mempercepat penyelesaian pekerjaan, juga untuk menghindari terjadinya hal-hal yang tidak diinginkan seperti kerusakan atau hilangnya data atau informasi. Sebagai contoh bila seseorang yang bekerja di bagian keuangan atau accounting department membutuhkan informasi pengiriman barang atau penjualan maka dia harus meminta data tersebut ke bagian yang dimaksud. Bila cara penyampaiannya masih bersifat manual dengan menggunakan peralatan-peralatan penyimpanan seperti disket, maka jumlah informasi yang bisa disimpan tentu terbatas, dan cara ini sangat rentan dengan kerusakan. Bila media penyimpanannya mengalami kerusakan maka data yang disimpan juga tentu tidak dapat dibuka untuk dipergunakan.

Untuk itu sistem jaringan sebaiknya dipergunakan bagi perusahaan-perusahaan besar yang memiliki jumlah komputer yang banyak dan tersebar pada area yang luas. Perusahaan ini memiliki area yang sangat luas dan terdiri dari banyak departemen atau bagian, yang mana setiap departemen memiliki masing-masing sebuah komputer diruangannya untuk mengolah dan menyimpan informasi sesuai dengan bidang pekerjaannya. Bilamana data yang diolah telah selesai dikerjakan, maka informasi yang dihasilkan akan dicetak dan kemudian di perbanyak dengan memfoto copy barulah disampaikan secara manual dari satu departemen atau bagian ke departemen lainnya. Tentunya hal ini sangat tidak efektif dan efisien. Tidak efektif bila kita 
memandang dari segi waktu dan tidak efisien bila dilihat dari segi biaya untuk memfoto copy.

Kemudahan yang disediakan oleh teknologi jaringan juga harus dibarengi dengan antisifasi akan kelemahannya. Kelemahan yang dimaksud salah satunya yaitu adanya orang ketiga yang tidak berwenang yang berusaha membuka data-data dan informasi penting perusahaan yang tersimpan didalam komputer. Dan juga bagaimana mengantisifasi setiap komputer yang ada dari serangan virus.

Pada dasarnya segala kegiatan penyampaian informasi bisa saja dilakukan secara manual seperti yang sudah berlangsung jauh sebelum sistem jaringan khususnya jaringan secara lokal atau LAN (Local Area Network) dikembangkan dan direalisasikan dalam perkomputeran kegiatan perkantoran perusahaan. Namun mengingat semakin terbatasnya waktu dalam menyajikan informasi maka sistem jaringan khususnya jaringan secara lokal atau LAN adalah alternatif yang tepat dan baik untuk dibangun pada sebuah perusahaan yang memiliki jumlah komputer yang banyak dan terletak dengan jarak yang berjauhan keberadaannya satu dengan lainnya. Komunikasi antar komputer secara jaringan lokal cukup dapat dihandalkan untuk saling berbagi data dan informasi. Banyak manfaat yang bisa diperoleh dengan pemanfaatan teknologi jaringan secara lokal atau local area network ini diantaranya adalah efisiensi dan efektifitas, yaitu efisiensi waktu dan biaya serta efektifitas pemanfaatan informasi yang disampaikan.

Pada setiap departemen dilengkapi dengan komputer sebagai alat pengolah dan penyimpan data yang berkaitan dengan kegiatan masing-masing bagian atau departemen. Sebagai contoh untuk Accounting Department, komputer digunakan untuk mengolah dan menyimpan data-data keuangan, Shipping Department mengolah dan menyimpan data-data pengiriman barang, Planning Department mengolah dan menyimpan data dan informasi jadwal pengiriman barang, Planning Department berkaitan dengan data dan informasi pemasaran. Setelah meninjau secara langsung pada perusahaan tersebut ternyata sistem komputerisasinya masih bersifat stay alone atau berdiri sendiri. Informasi yang dihasilkan dari setiap bagian akan dicetak kemudian diperbanyak untuk disampaikan kepada departmen atau bagian yang lain. Sangat memakan waktu dan biaya produksi dari sisi pemakaian kertas.

Dalam pembangunan sistem jaringan secara lokal atau LAN, keamanan jaringan juga harus diperhatikan. Agar tidak sembarang orang dapat mengakses komputer yang ada pada setiap bagian atau departemen, maka setiap komputer diletakkan diruangan yang tertutup untuk orang banyak. Hanya yang berwenang yang diperbolehkan untuk masuk keruangan tersebut dan mengoperasikan komputer yang ada. Keamanan secara software juga tidak boleh terabaikan. Setiap komputer diberikan passwords pada sistem bios-nya dan di-install-kan perangkat lunak (software) antivirus pada setiap komputer guna mencegah terserang virus yang berasal dari media penyimpanan tambahan seperti disket, flash disk dan lainnya.

Dengan pembangunan jaringan secara lokal ini diharapkan penyajian informasi dari satu departemen terhadap departemen 
atau bagian yang lain menjadi lebih mudah dan pemilihan sistem keamanan yang tepat akan menghindarkan terjadinya hal-hal yang tidak diinginkan seperti terserang virus atau pun terakses oleh orang yang tidak berwenang.

\section{Jaringan (Networking)}

LAN dapat definisikan sebagai network atau jaringan sejumlah sistem komputer yang lokasinya terbatas didalam satu gedung, satu kompleks gedung atau suatu kampus dan tidak menggunakan media fasilitas komunikasi umum seperti telepon, melainkan pemilik dan pengelola media komunikasinya adalah pemilik LAN itu sendiri. Dari definisi diatas dapat kita ketahui bahwa sebuah LAN dibatasi oleh lokasi secara fisik. Adapun penggunaan LAN itu sendiri mengakibatkan semua komputer yang terhubung dalam jaringan dapat bertukar data atau dengan kata lain berhubungan. Kerjasama ini semakin berkembang dari hanya pertukaran data hingga penggunaan peralatan secara bersama.

LAN yang umumnya menggunakan $h u b$, akan mengikuti prinsip kerja $h u b$ itu sendiri. Dalam hal ini adalah bahwa hub tidak memiliki pengetahuan tentang alamat tujuan sehingga penyampaian data secara broadcast dan juga karena hub hanya memiliki satu domain collision sehingga bila salah satu port sibuk maka port-port yang lain harus menunggu.

\section{Komponen-komponen Dasar LAN}

Beberapa komponen dasar yang biasanya membentuk suatu LAN adalah sebagai berikut:

\section{A. Workstation}

Workstation merupakan node atau host yang berupa suatu sistem kom- puter. Sistem komputer ini dapat berupa PC atau dapat pula berupa suatu komputer yang besar seperti sistem minicomputer, bahkan suatu mainframe. Workstation dapat bekerja sendiri (stand-alone) dapat pula menggunakan jaringan untuk bertukar data dengan workstation atau user yang lain.

B. Server

Perangkat keras (hardware) yang berfungsi untuk melayani jaringan. Sumber daya (resources) seperti printer, disk dan sebagainya yang hendak digunakan secara bersama oleh para pemakai di workstation berada dan bekerja pada server. Berdasarkan jenis pelayanannya dikenal disk server, file server, print server dan suatu server juga dapat mempunyai beberapa fungsi pelayanan sekaligus.

C. Link (hubungan)

Workstation dan server tidak dapat berfungsi apabila peralatan tersebut secara fisik tidak terhubung. Hubungan tersebut dalam LAN dikenal sebagai media transmisi yang umumnya berupa kabel. Adapun beberapa contoh dari link adalah:

1. Kabel Twisted Pair

Kabel ini terbagi dua, yaitu Shielded Twisted Pair dan Unshielded Twisted Pair (UTP)

a. Lebih banyak dikenal karena merupakan kabel telpon.

b. Relatif murah.

c. Jarak yang pendek.

d. Mudah terpengaruh oleh gangguan.

e. Kecepatan data yang dapat 
didukung terbatas, 10-16 Mbps.

2. Kabel Coaxial

a. Umumnya digunakan pada televise.

b. Jarak yang relatif lebih jauh.

c. Kecepatan pengiriman data lebih tinggi di banding Twisted Pair, 30 Mbps.

d. Harga yang relatif tidak mahal.

e. Ukurannya lebih besar dari Twisted Pair.

3. Kabel Fiber Optic

a. Jarak yang jauh.

b. Kecepatan data yang tinggi 100 Mbps.

c. Ukuran yang relatif kecil.

d. Sulit dipengaruhi gangguan.

e. Harga yang relatif masih mahal.

f. Instalasi yang relatif sulit.

D. Network Interface Card (NIC)

Suatu workstation tidak dihubungkan secara langsung dengan kabel jaringan ataupun tranceiver cable, tetapi melalui suatu rangkaian elektronika yang dirancang khusus untuk menangani network protocol yang dikenal dengan Network Interface Card (NIC).

\section{E. Network Software}

Tanpa adanya software jaringan maka jaringan tersebut tidak akan bekerja sebagaimana yang dikehendaki. Software ini juga yang memungkinkan sistem komputer yang satu berkomunikasi dengan sistem komputer yang lain. Peralatan Pendukung
LAN:

1. Repeater

a. Pada OSI, bekerja pada lapisan Physical.

b. Meneruskan dan memperkuat sinyal.

c. Banyak digunakan pada topologi Bus.

d. Penggunaannya mudah dan harga yang relatif murah.

e. Tidak memiliki pengetahuan tentang alamat tujuan sehingga penyampaian data secara broadcast.

f. Hanya memiliki satu domain collision sehingga bila salah satu port sibuk maka port-port yang lain harus menunggu.

2. Hub

a. Bekerja pada lapisan Physical.

b. Meneruskan sinyal.

c. Tidak memiliki pengetahuan tentang alamat tujuan.

d. Penggunaannya relatif mudah dan harga yang terjangkau.

e. Hanya memiliki satu buah domain collision.

3. Bridge

a. Bekerja di lapisan Data Link.

b. Telah menggunakan alamatalamat untuk meneruskan data ke tujuannya.

c. Secara otomatis membuat tabel penterjemah untuk diterima masing-masing port. 
4. Switch
a. Bekerja di lapisan Data Link.
b. Setiap port didalam switch memiliki domain collision sendiri-sendiri.
c. Memiliki tabel penterjemah pusat yang memiliki daftar penterjemah untuk semua port.
d. Memungkinkan transmisi secara full duflex (dua arah).

5. Router

a. Router berfungsi menyaring atau mem-filter lalu lintas data

b. Menentukan dan memilih jalur alternatif yang akan dilalui oleh data Menghubungkan antar jaringan LAN, bahkan dengan WAN

\section{Topologi LAN}

Pengertian topologi jaringan adalah susunan lintasan aliran data didalam jaringan yang secara fisik menghubungkan simpul yang satu dengan simpul lainnya. Berikut ini adalah beberapa topologi jaringan yang ada dan dipakai hingga saat ini, yaitu:

\section{A. Topologi Star}

Beberapa simpul Inode dihubungkan dengan simpul pusat/host, yang membentuk jaringan fisik seperti bintang, semua komunikasi ditangani langsung dan dikelola oleh host yang berupa mainframe komputer.

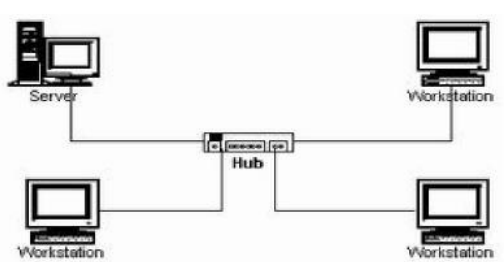

Gambar 2.3 Topologi Star

\section{B. Topologi Hierarkis}

Berbentuk seperti pohon bercabang yang terdiri dari komputer induk (host) dihubungkan dengan simpul Inode lain secara berjenjang. Jenjang yang lebih tinggi berfungsi sebagai pengatur kerja jenjang dibawahnya.

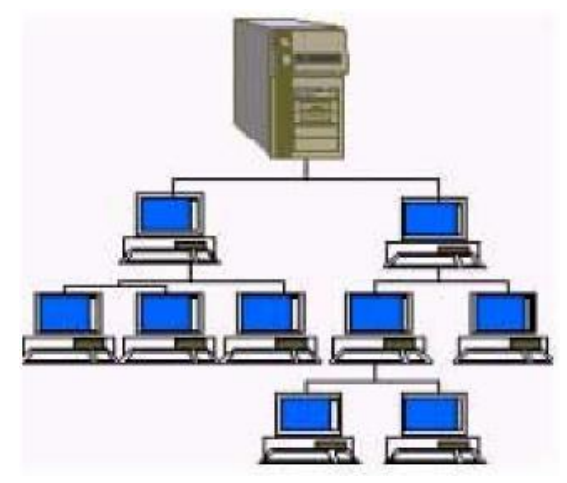

Gambar 2.4 Topologi Hierarkis

\section{Topologi Bus}

Beberapa simpul Inode dihubungkan dengan jalur data (bus). Masingmasing node dapat melakukan tugastugas dan operasi yang berbeda namun semua mempunyai hierarki yang sama.

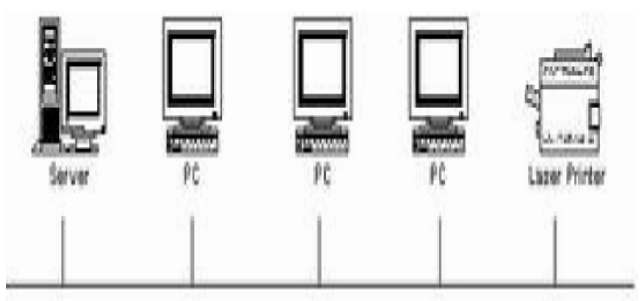

Gambar 2.5 Topologi Bus 
D. Topologi Loop

Merupakan hubungan antar simpul Inode secara serial dalam bentuk suatu lingkaran tertutup. Dalam bentuk ini tak ada central node/host, semua mempunyai hierarki yang sama.

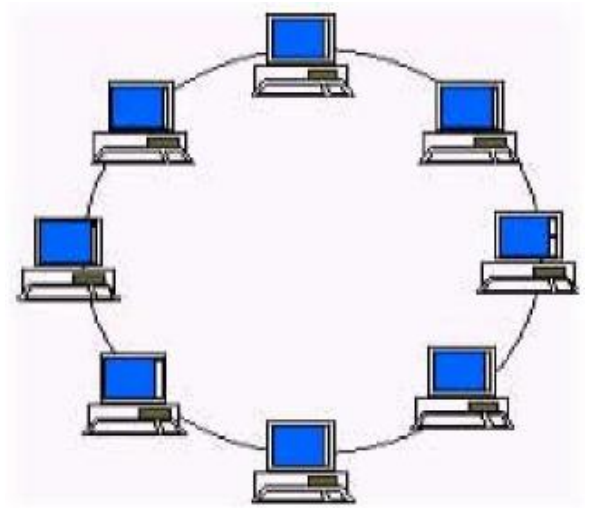

Gambar 2.6 Topologi Loop

\section{E. Topologi Ring}

Bentuk ini merupakan gabungan bentuk topologi loop dan bus, jika salah satu simpul Inode rusak, maka tidak akan mempengaruhi komunikasi node yang lain karena terpisah dari jalur data.

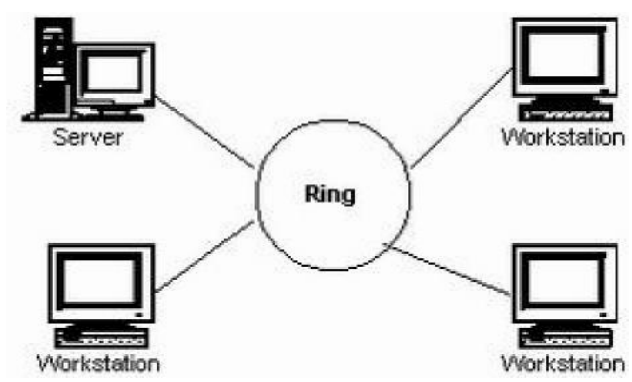

Gambar 2.7 Topologi Ring

\section{F. Topologi Web}

Merupakan bentuk topologi yang masing-masing simpul Inode dalam jaringan dapat saling berhubungan dengan node lainnya melalui bebe- rapa link. Suatu bentuk web network dengan $\mathrm{n}$ node, akan menggunakan link sebanyak n(n-1)/2.

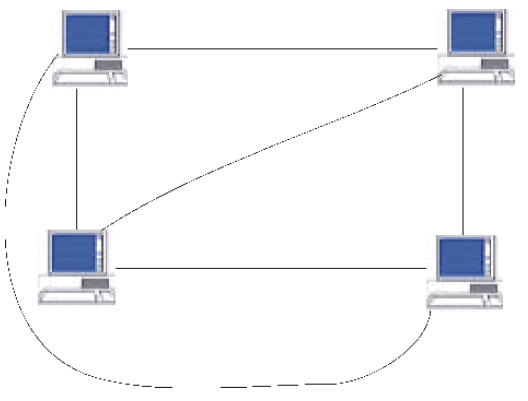

Gambar 2.8 Topologi Web

Dengan menggunakan segala kelebihan dan kekurangan masing-masing konfigurasi, memungkinkan dikembangkannya suatu konfigurasi baru yang menggabungkan beberapa topologi disertai teknologi baru agar kondisi ideal suatu sistem jaringan dapat terpenuhi.

\section{Prosedur Kerja Pengiriman Berkas}

Sistem pengiriman berkas yang sedang berjalan sebelumnya adalah secara manual. yaitu dengan mencetak, memperbanyak dan disebarkan atau menyimpan kedalam media disket yang rentan terhadap kerusakan.

Efektifitas waktu yang dibutuhkan juga kurang efisien, karena dalam pengiriman data atau berkas tersebut banyak waktu yang terbuang. Belum lagi jika dalam perjalanan ke departemen tersebut data hilang atau rusak. Hal ini akan menambah beban kerja, sehingga pekerjaan menjadi rumit.

\section{Evaluasi Sistem}

Untuk mendesain suatu sistem, maka perlu melakukan evaluasi sistem yang telah ada dan dari hasil analisis terhadap sistem 
yang ada maka terdapat beberapa permasalahan yang terjadi, yang mengakibatkan kurang efisien dan efektifnya pekerjaan.

1. Sistem penyampaian data masih bersifat manual dan menggunakan metode penyimpanan data yang masih konvensional. Hal ini akan berdampak pada lambatnya proses pengiriman data.

2. Sulitnya mengetahui tentang perkembangan masalah yang telah diselesaikan karena masih menggunakan caracara konvensional seperti dengan cara menyimpan data ke media penyimpan disk yang dapat berakibat kehilangan atau kerusakan data yang disebabkan oleh kelupaan dan kehilangan dokumentasi.

\section{Desain Sistem Baru}

Desain sistem dapat didefinisikan sebagai penggambaran, perencanaan dan pembuatan sketsa atau pengaturan dari beberapa elemen yang terpisah ke dalam satu kesatuan yang utuh dan berfungsi. Dengan demikian tahap desain sistem dapat diartikan :

1. Tahap setelah analisis dari siklus pengembangan sistem

2. Pendefinisian dari kebutuhan-kebutuhan fungsional

3. Persiapan untuk rancang bangun implementasi

4. Menggambarkan bagaimana suatu sistem dibentuk

5. Penggambaran, perencanaan dan pembuatan sketsa atau pengaturan dari beberapa elemen yang terpisah ke dalam satu kesatuan yang utuh dan berfungsi.

Sedangkan tujuan dari sistem yang baru yaitu :
1. Untuk memenuhi kebutuhan pengguna sistem

2. Untuk memberikan gambaran dari rancang bangun yang lengkap kepada pemrogram komputer dan ahli-ahli yang terkait

Untuk mencapai tujuan ini, maka ada sasaran yang harus dicapai yaitu :

1. Desain sistem harus bermanfaat, mudah dipahami dan nantinya mudah digunakan. Ini berarti data harus mudah dimanfaatkan, metode-metode harus mudah diterapkan dan informasi harus mudah dihasilkan serta mudah dipahami serta mudah digunakan

2. Desain sistem harus dapat mendukung tujuan utama perusahaan/ instansi.

3. Desain sistem harus efisien dan efektif untuk dapat mendukung pembuatan laporan dan mendukung keputusan yang akan dilakukan oleh pimpinan termasuk tugas-tugas yang lainnya.

4. Desain sistem harus dapat mempersiapkan rancang bangun yang terinci untuk masing-masing komponen dari sistem informasi yang meliputi data, informasi, simpanan data, metodemetode, perangkat lunak, perangkat keras dan pengendalian sistem.

Dalam proses pembangunan sistem melalui beberapa tahapan, dari sistem itu direncanakan hingga dengan sistem tersebut digunakan sehingga bermanfaat bila ditinjau dari:

1. Kelancaran arus komunikasi data

2. Penghematan biaya

3. Kelengkapan informasi dan keterpaduan sistem 
4. Kebenaran dan kemuktahiran informasi yang digunakan

Sesuai analisis dan hasil evaluasi yang dijelaskan sebelumnya, maka dilakukan desain sistem pengiriman data terutama dalam membangun suatu konsep jaringan LAN (Local Area Network) yang diharapkan dapat menghilangkan dampak negatif sistem manual. Desain sistem secara umum dapat dilihat pada Aliran Sistem Informasi (ASI) yang baru dan Data Flow Diagram (DFD) yang merupakan pengembangan desain dari sistem yang ada.

Secara konseptual, jaringan yang lama adalah dengan menggunakan topologi sebagai berikut :

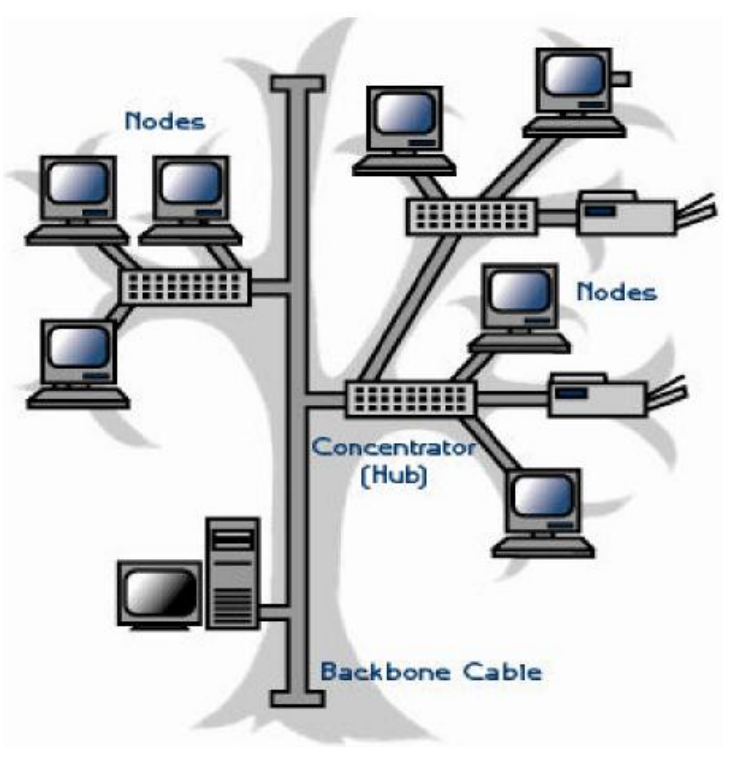

Gambar 3.1 Konsep Jaringan Tree

Topologi yang akan dibangun adalah Topologi Tree yaitu kombinasi dari beberapa topologi seperti yang dapat dilihat pada gambar 3.1 Konsep Jaringan Tree. Dari gambar tersebut bahwa pada back- bone adalah memanfaatkan linear topologi bus dan untuk menghubungkan antar node adalah menggunakan topologi star.

\section{Aliran Sistem Informasi (ASI) Baru}

Desain sistem yang baru ini dimaksudkan untuk mengatasi kelemahan dan hambatan pada sistem yang sedang berjalan, disamping memberikan perbaikan terhadap sistem tersebut. Hal ini karena sistem pengolahan data yang baik harus memenuhi kriteria-kriteria sebagai berikut :

1. Cepat, yaitu dapat menyajikan informasi tepat pada waktunya.

2. Ekonomis, bahwa dapat menghemat biaya administrasi seminimal mungkin.

3. Akurat dan teliti dalam pengolahan data sebagai informasi yang dibutuhkan.

Untuk mendukung kriteria-kriteria sistem tersebut diatas, maka sistem pengolahan pengiriman data harus berdampak:

1. Memberitahukan cara yang lebih cepat dan lebih baik kepada setiap bagian perusahaan dalam melayani kebutuhan informasi bagi yang membutuhkan.

2. Menekan biaya administrasi serendah mungkin

3. Untuk memenuhi kebutuhan user (pemakai)

Pada desain sistem yang baru sebagian proses yang dilakukan telah menggunakan sistem jaringan sebagai alat bantu di dalam proses pengiriman data.

\section{Desain Sistem Terinci}

Desain sistem terinci ini menggambarkan atau menjelaskan bagaimana dan 
seperti apa secara detail komponen-komponen atau variabel-variabel dari sistem jaringan seperti desain peripheral (masukan), desain network (keluaran).

\section{Metode Penyelesaian Masalah}

Alternatif Pemecahan masalah yang akan ditempuh adalah merancang sebuah Sistem Jaringan yang akan dirancang dengan menggunakan Topologi Tree. Latar belakang penggunaan topologi ini adalah karena dianggap topologi ini umum dipakai pada saat ini serta mudah untuk menerapkannya.

\section{Prosedur Membangun Jaringan}

Adapun langkah-langkah penyusunannya adalah sebagai berikut:

1. Menyediakan perangkat keras (hardware) dan perangkat lunak (software). Menyediakan segala perangkat lunak sistem operasi komputer dan perangkat keras komputer yang dibutuhkan.

2. Menyediakan Desain Sistem. Desain sistem untuk penyusunan program ini terdiri dari pemasangan dan seting sistem.

\section{Komponen Utama}

Faktor utama yang paling mendukung adalah faktor manusia (brainware) selaku sumber daya yang berperan penting dalam mengelolah dan mengimplementasikan sistem yang telah dibuat. Selain itu sistem tidak akan dapat bekerja dan berjalan sebagaimana yang diharapkan bila tidak adanya faktor pendukung seperti perangkat keras (hardware) dan perangkat lunak (software).

\section{Perangkat Keras (Hardware)}

Hardware adalah seluruh komponen- komponen peralatan yang membentuk suatu sistem komputer dan peralatan lainnya yang memungkinkan komputer dapat melaksanakan tugasnya.

Sesuai dengan fungsinya, perangkat keras terdiri dari empat komponen utama, yaitu:

1. Alat Masukan (Input Device)

Input Device adalah alat atau perangkat yang digunakan untuk melakukan proses penginputan dan pemasukan data ke dalam sistem. Contoh keyboard, pointing device, scanner dan lain sebagainya.

2. Central Processing Unit (CPU)

CPU merupakan tempat pemrosesan instruksi-instruksi program. CPU merupakan jantung dari komputer. Komponen merupakan pusat pengolahan serta pusat pengontrolan dari keseluruhan sistem komputer yang sedang melaksankan suatu kegiatan.

3. Alat Keluaran (Output Device)

Output Device adalah alat yang menerima hasil pengolahan data dari CPU melalui main storage dan akan menghasilkan keluaran baik berupa tampilan data pada layar monitor maupun cetakan data pada kertas melalui alat printer.

4. Simpanan Luar (External Storage) Main memory di dalam alat pemroses merupakan simpanan yang kapasitasnya tidak begitu besar. Simpanan yang memiliki ciri-ciri tersebut adalah external memory karena terletak di luar alat prosesnya. 


\section{Perangkat Lunak (Software)}

Perangkat keras komputer tidak akan dapat berbuat apa-apa tanpa adanya perangkat lunak. Teknologi yang canggih dari perangkat keras akan berfungsi bila instruksi-instruksi tertentu telah diberikan kepadanya. Instruksi-instruksi tersebut disebut dengan software. Instruksi-instruksi perangkat lunak ditulis oleh manusia untuk mengaktifkan fungsi dari perangkat keras komputer.

\section{Sumber Daya Manusia (Brainware)}

Brainware merupakan komponen manusia yang terlibat langsung dalam pengoperasian komputer dan melaksanakan semua kegiatan yang berhubungan dengan hardware dan software.

Pada umumnya, brainware digolongkan menjadi 4 bagian, yaitu :

1. System Analyst yaitu orang yang akan membentuk dan membangun fasilitas system design.

2. Programmer, merupakan orang yang akan menyusun instruksi bagi komputer.

3. Engineer merupakan orang yang bertanggung jawab dalam perawatan perangkat keras dan perangkat lunak.

4. Operator merupakan orang yang akan menangani secara langsung pengolahan data dalam komputer.

\section{Pemasangan dan Setting Sistem}

Kegiatan pemasangan ataupun penerapan sistem akan dibagi dalam beberapa bentuk pengaturan, antara lain :

A. Kabel Jaringan

Untuk menghubungkan jaringan diperlukan kabel Ethernet yaitu kabel yang digunakan disebut kabel UTP (Unshielded Twisted Pair) dengan menggunakan konektor RJ45. Kabel UTP mempunyai delapanpin (4 pasang).

a. Pinl dengan warna hijau-putih (TD+)

b. Pin2 dengan warna hijau (TD-)

c. Pin3 dengan warna orange-putih (RD+)

d. Pin4 dengan warna biru (NC)

e. PinS dengan warna biru-putih (NC)

f. Pin6 dengan warna orange (RD-)

g. Pin7 dengan warna coklat-putih (NC)

h. Pin8 dengan warna coklat (NC)

Konfigurasi kabel adalah sebagai berikut :
T-568B

12234456778

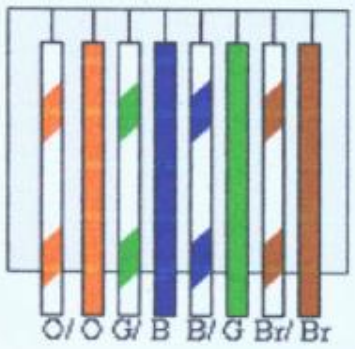

T-568A

$\begin{array}{llllllll}1 & 2 & 3 & 4 & 5 & 6 & 7 & 8\end{array}$

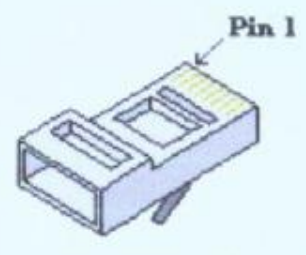

RJ-45 Plug

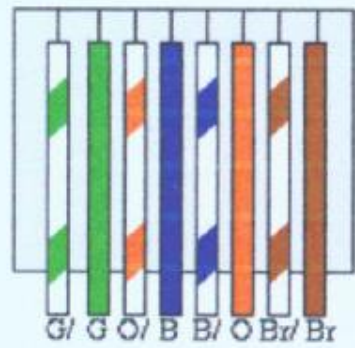

Gambar 4.1 Konfigurasi Kabel 
Ada tiga cara pemasangan kabel adalah sebagai berikut :

1. Straight Through

Pengkabelan jenis ini biasanya diperuntukkan untuk menghu- bungkan peralatan yang berbeda jenis. Misal untuk menghubungkan PC dengan hub, switch dan router, switch dan PC dan sebagainya.
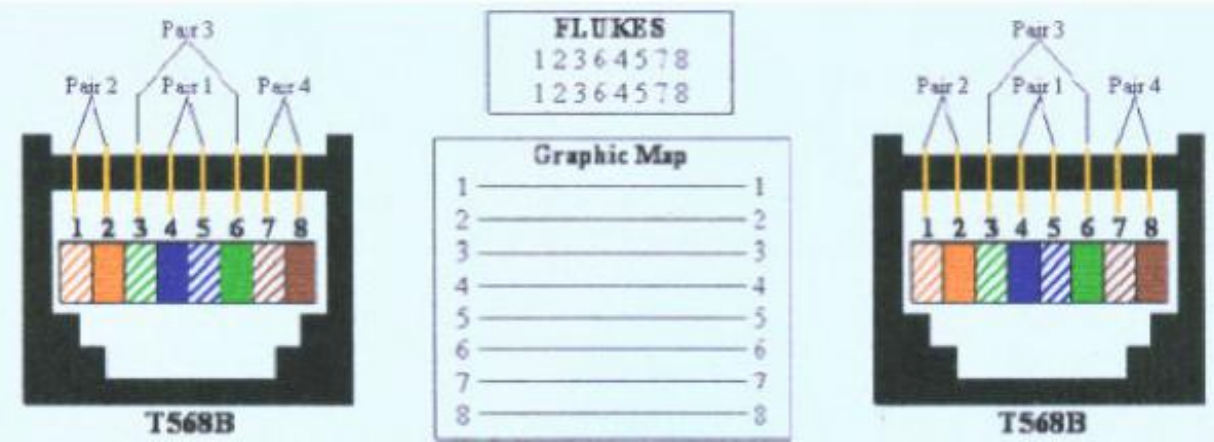

Gambar 4.2 Penampang Straigh Through

2. Cross Over

Pengkabelan jenis ini biasanya digunakan untuk menghubungkan peralatan sejenis. Misal un- tuk menghubungkan $\mathrm{PC}$ dengan $\mathrm{PC}$, hub dengan hub dan sebagainya.
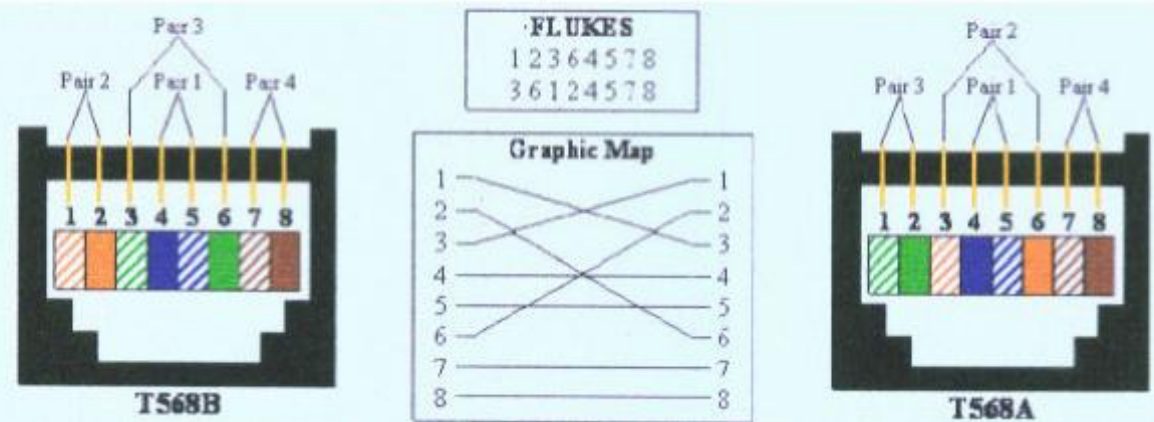

Gambar 4.3 Penampang Cross Over

3. Rollover

Pengkabelan jenis ini merupakan pengkabelan khusus. Misalnya untuk menghubungkan antar switch. 

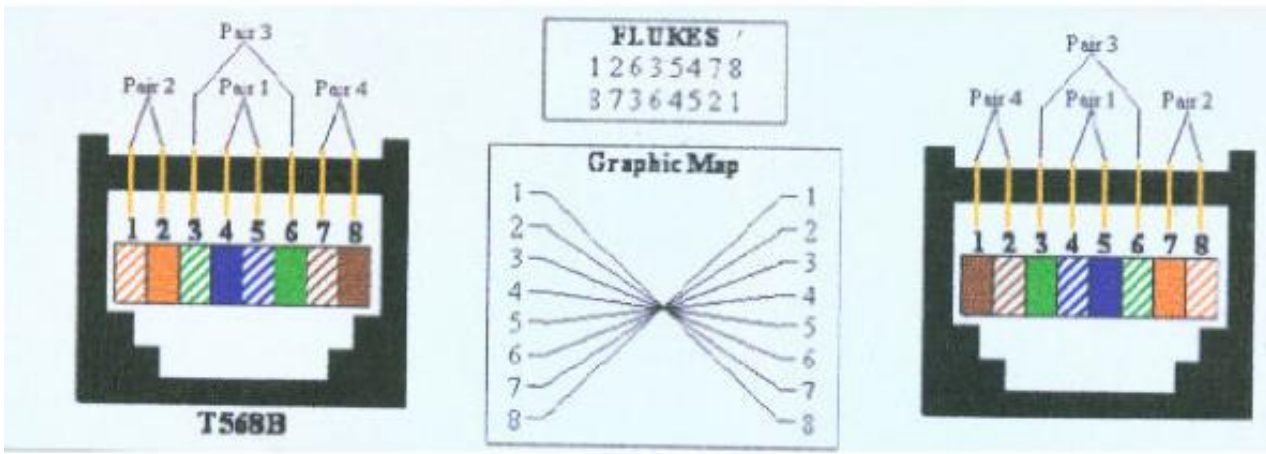

Gambar 4.4 Penampang RollOverr

Setelah pemasangan kabel selesai, kemudian dilakukan pengetesan pemasangan kabel menggunakan cable tester. Langkah selanjutnya adalah pengaturan sistemnya.

\section{B. Setting Sistem}

Pengaturan terhadap sistem yang ada dikonfigurasikan sesuai dengan sistem operasi yang berlaku. Adapun langkah-langkah pengaturan antara

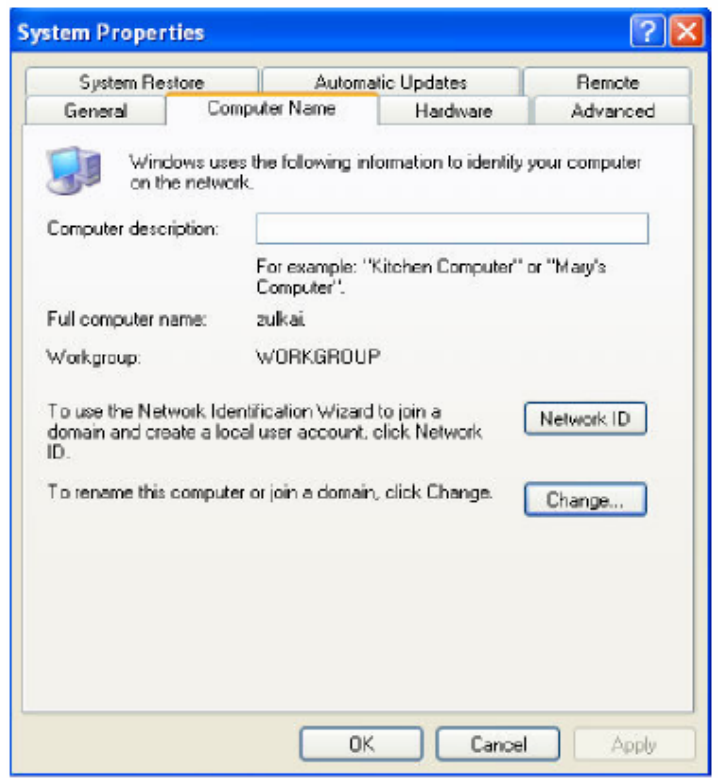

lain sebagai berikut :

a. Pemberian Nama Komputer (Computer Name)

Nama Komputer di bagian pembuatan jaringan komputer dibutuhkan untuk mengidentifikasikan nama pengguna yang dikenal oleh pengguna jaringan lainnya agar dapat berbagi informasi.

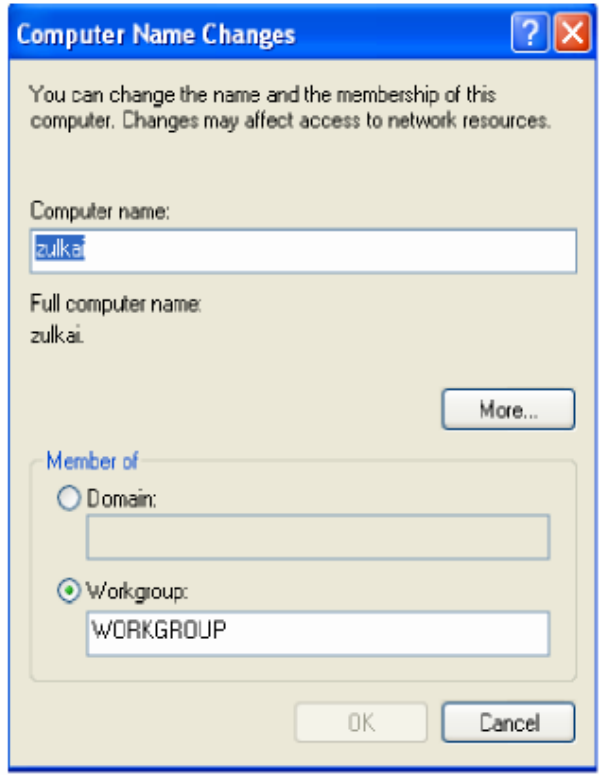

Gambar 4.5 Pengaturan Computer Name dan Workgroup 
b. Konfigurasi TCP/IP

Transmission Control Protocol

/ Internet Protocol (TCP/IP)

dibuat oleh Department of

Defense (DoD) untuk memasti- kan dan menjaga integritas data sama seperti halnya menjaga komunikasi dalam situasi kekacauan perang.
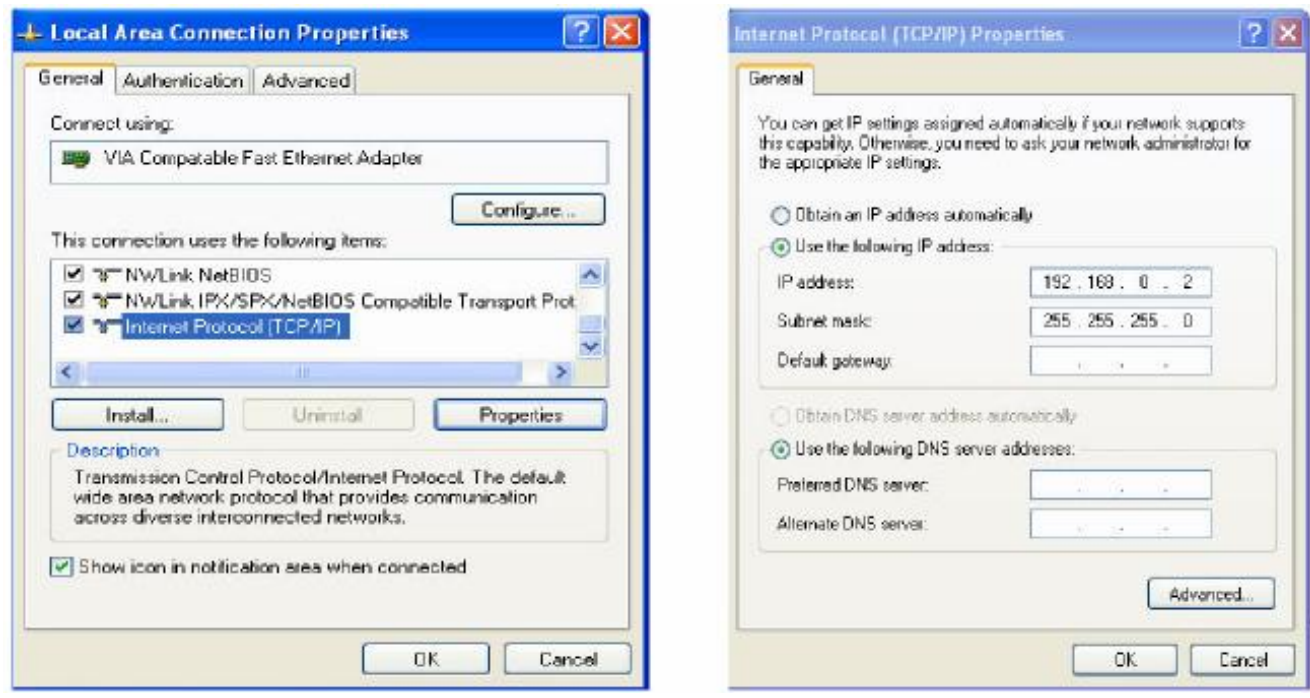

Gambar 4.6 Pemberian IP address dan Subnet mask

c. Pengaturan Folder yang disharing

Folder yang di-sharing disini adalah merupakan folder yang digunakan sebagai tempat menyimpan data yang dibutuhkan oleh departemen lain, sehingga departemen lainnya dapat mengambil data di-folder tersebut tanpa meminta secara langsung ke departemen yang bersangkutan.

\section{Program Proteksi Suatu Folder}

Perlu diingat agar pihak-pihak yang tidak berwenang tidak dapat mengakses data yang ada pada suatu folder terutama yang datanya sangat penting, maka folder tersebut perlu diproteksi dengan program enkripsi. Untuk itu kita perlu meng-install program enkripsi tersebut kedalam kom- puter kita.

\section{Utility Penguji Keamanan}

Utility merupakan suatu program yang telah dibangun yang memiliki satu fungsi tertentu didalam sistem. Secara umum, ada tiga utility yang digunakan dalam penulisan skripsi ini, yaitu :

1. Utility Penguji Jaringan

Jaringan yang telah dibangun harus dilakukan pengujian apakah jaringan tersebut telah sesuai dengan kebutuhan atau tidak. Paling tidak, jaringan harus mampu membagi data atau informasi untuk pengguna lainnya sesuai dengan kebutuhan. Netsupport merupakan salah satu utility yang dibangun untuk memanajemen jaringan lokal. Secara umum, banyak bentuk dan hal-hal yang dapat dilakukan 
oleh utility ini. Antara lain, mengirim pesan. Untuk menggunakannya, kita harus menginstalnya terlebih dahulu. Setelah berhasil maka kita dapat mengujinya.

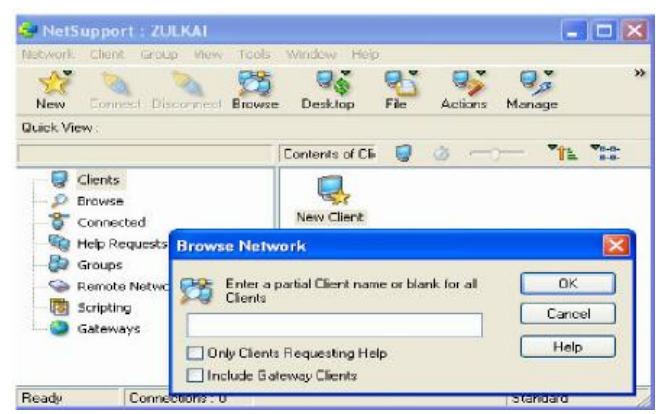

Gambar 4.15 Tampilan Netsupport

2. Utility Menjebol Jaringan

Rasa ingin tahu manusia itu wajar. Mendengar kata passwords pasti semua setuju bahwa passwords berhubungan dengan sesuatu yang rahasia. Dan sesuatu yang rahasia itu harus dijaga benar-benar jangan sampai orang tahu. Dalam jaringan (LAN) dikantor atau di warnet terdapat fasilitas file sharing dimana setiap komputer berhak me-share file dan juga memberikan hak akses. Hak akses tersebut bisa berupa read only atau full access. Jika anda pengguna Microsoft Windows jangan pernah melakukan file sharing di network neighborhood karena sangat mudah untuk menjebol passwords network neighborhood. Tidak ada syarat atau kemampuan khusus, Cuma beberapa istilah yang harus di mengerti yaitu, hostname dan IP Address.

Passwords windows untuk network neighborhood disimpan dengan huruf kapital. Walaupun anda memasukkan passwords berupa huru kecil maka otomatis windows akan mengkonversi menjadi huruf kapital.

3. Utility Menjaga Keamanan Sistem

Di samping pengamanan secara fisik, Anda juga memerlukan pengamanan sistem melalui berbagai perangkat (tools) yang ada pada sistem itu sendiri. Pengamanan ini berguna dalam mengantisipasi penggunaan jaringan yang terhubung dengan PC Anda, lebih-lebih bilamana PC Anda merupakan server utama yang bertugas melayani beragam keperluan dari client, baik lokal maupun Internet. Berbagai bentuk perlindungan ada di Internet, baik yang ditawarkan sebagi program komersial seperti Xsentry, maupun yang bersifat GPL atau free.

\section{Pemasangan firewall}

Jika Anda mempunyai beberapa buah komputer yang saling terhubung lewat jaringan (ethernet misalnya), dapat menggunakan linux sebagai pintu gerbang (router/gateway) untuk menyambungkan semua komputer Anda menuju Internet. Router dan gateway sendiri sebenarnya secara teori mempunyai filosofi arti yang berbeda. Gateway sebenarnya mengacu pada alat yang difungsikan untuk menjembatani dua buah jaringan yang mempunyai topologi berbeda, berbeda subnet dan sebagainya. Sedangkan router adalah untuk mengatur pengalamatan paket-paket data dalam jaringan yang berbeda sehingga komunikasi dapat terlaksana. Akan tetapi, dalam kenyataan sehari-hari router dan gateway sering kali hanya ditangani oleh sebuah alat saja. Hal inilah yang menyebabkan router selalu diidentikkan 
dengan gateway, demikian pula sebaliknya yakni gateway identik dengan router. Pada saat PC kita bisa berhubungan satu sama lain, maka akan kita temui satu persoalan baru, yaitu bagaimana agar kita tidak kedatangan "tamu tak diundang". Untuk itulah kita buat firewall. Jika server Anda bukan merupakan layanan untuk publik, tentukan dari host/IP mana saja yang diizinkan untuk mengakses ke server Anda, kemudian lakukan DENY/DROP/REJECT terhadap paket-paket yang bukan dari host/IP yang Anda izinkan. Gunakan ipfwadm/ipchains/iptables, ipfw atau ipf untuk melakukan filtering/firewalling.

Firewall adalah suatu cara untuk membatasi informasi yang dibolehkan masuk dan keluar dari jaringan lokal Anda. Umumnya host firewall terhubung ke Internet dan LAN lokal Anda dan akses LAN Anda ke Internet hanya melalui firewall. Dengan demikian, firewall dapat mengendalikan apa yang diterima dan dikirim dari Internet dan LAN Anda. Firewall adalah teknik yang sangat berguna dan penting dalam mengamankan jaringan. Penting untuk menyadari bahwa tidak boleh berfikir bahwa dengan memiliki firewall, kita tidak perlu mengamankan mesin-mesin dibaliknya. Ini kesalahan fatal. Periksa Firewall-HOWTO yang sangat bagus diarsip terbaru sunsite untuk informasi mengenai firewall dan linux pada http://sunsite.unc.edu/mdw/ HOWTO/firewallHOWTO.html.

\section{Setting Firewall}

Setting firewall personal ini sekilas kelihatan ruwet, namun sebenarnya tidak begitu. Disini diikutsertakan masquerading, karena bilamana rekan kita yang membawa laptop ingin "masuk" jaringan
Internet, ataupun berbagi file dan data, maka kita akan membukanya satu persatu. Selain itu, sebagai antisipasi bilamana ada rekan kita yang usil "ngerjain" PC Anda.

\section{Pemasangan firewall dengan Iptables}

Penggunaan Iptables ini diperuntukkan bagi yang menggunakan kernel 2.4.x. Program Iptables ini lebih lengkap dari segi fasilitasnya dan juga lebih "aman" dibandingkan Ipchains. Disarankan untuk menggunakan Iptables versi 1.2.5 ke atas untuk lebih amannya.

\section{Penggunaan Portsentry}

Portsentry dirancang khusus untuk memperlambat proses penjejakan (scanning) yang biasa dilakukan oleh user.

\section{Kesimpulan}

Dengan diterapkannya sistem jaringan ini diharapkan segala kendala tentang keterlambatan dan ketidak akuratan laporan-laporan yang berhubungan dengan masalah pengiriman data dapat diatasi, bahkan mempercepat pengolahan data yang selama ini terkesan sangat lambat.

Output atau keluaran yang dihasilkan harus selalu diamati, karena dengan berubahnya tatanan pengolahan pengiriman data, akan berubah pula kebutuhan akan sistem tersebut. Jika terjadinya perubahan kebutuhan sistem, maka untuk dapat menyediakan informasi dan laporan yang aktual serta keamanan data perlu adanya diadakan lagi tahap-tahap pembuatan suatu sistem pengamanan seperti yang telah disimpulkan diatas. 


\section{Referensi}

Jogiyanto Hartono, MBA, Akt, Ph.D, Analisis Dan Desain Sistem Informasi: Pendekatan Terstruktur Teori dan Praktek Aplikasi Bisnis, PN. Andi Yogyakarta, Yogyakarta, 1999.

Jogiyanto Hartono, MBA, Akt., Ph.D, Pengenalan Komputer, PN. Andi Yogyakarta, Yogyakarta, Edisi ke-2, Cetakan I, 1999.

Richardus Eko Indrajit. Dr, Pengantar Konsep Manajemen Sistem Informasi Dan Teknologi Informasi, PN. PT. Elex Media Komputindo, Jakarta, 2000.
Todd Lammle, CCNA: Cisco Certified Network Associate, Kelompok Gramedia, PT. Elex Media Komputindo, Jakarta, 2005.

Tavri D. Mahyuzir, Analisa \& Perancangan Pengolahan Data, 1994, Elex Media Komputindo

http://www.downloadnetsupport.com/index .htm

http://www.sunsite.unc.edu/mdw/HOWTO /Firewall-HOWTO.html 